PLEASE NOTE! THIS IS SELF-ARCHIVED VERSION OF THE ORIGINAL ARTICLE

To cite this Article: Tossavainen, P. J. (2016) Co-create with stakeholders: Action research approach in service development. Action Research, 1-8.

URL: http://journals.sagepub.com/doi/abs/10.1177/1476750316641995

DOI: $10.1177 / 146750316641995$ 


\title{
Co-create with stakeholders: Action research approach in service development
}

\begin{abstract}
This paper promotes the value of including many stakeholders in service development. The experience of co-creative service development is examined through the lens of action research. Engaging multiple stakeholders in face-to-face, in simultaneous joint activities, from various organisations, with different levels of hierarchy, and dissimilar positions, may increase the diversification through the broadness of the information, knowledge, and experiences, and increase the amount, and quality of the development suggestions. This paper is an attempt to tell the story of action research and how it was applied to increase the understanding of the usefulness of multiple stakeholders in service development. Outcomes of a research project are presented. The paper ends with discussion of the theoretical and practical implications of the conducted research.
\end{abstract}

Keywords: co-creation, collaboration; multiple stakeholders, service development, action research, service research 


\section{Introduction to circular economy and the waste management service context}

The transition towards a circular economy to improve sustainability is on going. In a circular economy, the resource loops are closed, which also means that materials are recycled and energy is derived from renewable or otherwise sustainable sources. Environmentally sound products and services are needed alongside conscious decision-making to be sustainable. A participant of the project confirmed this in the interview:

"I am interested what really happens to the waste"

Yet, another participant revealed that in business environment the situation may be challenging

"If I would go and ask, I bet, that it is unclear for quite a many people, why it is worth of sorting waste ..."

The aim of this action research project is to develop the existing waste management service of the case company, Lassila \& Tikanoja Ltd (L\&T). L\&T is a large Finnish-based service firm with net sales of over 670M€ in 2012, over 9,000 employees, and operations in Finland, Latvia, Sweden, and Russia. In the near future, the need for recycling services is likely to increase. It is expected that L\&T will begin to purchase more waste as a raw material for energy production and other purposes.

The waste management service begins when firms (i.e. customers) sort their waste according to national and municipal regulations. The service provider (L\&T) collects the waste and transports it either through transfer stations or directly to the main waste processing centre to be tested and processed. It is noteworthy that after collecting the waste materials from many sources, the waste's origin can no longer be determined. The end result of the waste and its processing is sellable raw material in the form of a) landfill; b) burnable; and c) recycled waste material.

At L\&T, the waste management service was developed according to industrial logic (Vargo \& Lusch, 2004) that is within the case company and then sold to one customer at a time. This dyadic mode where interaction is based on one-to-one relationships is common. However, it is time consuming and implies unequal interactions with customers resulting in an imperfect waste 
management service because development needs arise after the service is already in use. The contemporary view on service research suggests that the service provider cannot create their service only by themselves as in the conventional industrial logic (Grönroos, 2011; Grönroos \& Voima, 2013; Prahalad \& Ramaswamy, 2004a, 2004b; Vargo \& Lusch, 2008). Bettencourt et al (2014) clarify this idea stating that value comes from job accomplishment (i.e. value-in-use), not during the acquisition of service (i.e. value-in-exchange). Especially, in the business-to-business (B2B) context, engagement and interaction among multiple stakeholders remains a challenge, as described in a customer interview:

"I have been in a large event a few years ago. I did not connect with anyone. We were just a large group of people, just sitting in a big room and listened"

Outside the L\&T contacts, the customer representatives in this project did not know each other and had not met one another before. One customer revealed in an interview that

"I don't know any other stakeholders (of L\&T)"

Thus, there were reasons to examine ways of enabling the stakeholders' co-creation as suggested by Prahalad and Ramaswamy (Prahalad \& Ramaswamy, 2004a, 2004b, 2004c; Ramaswamy \& Gouillart, 2010). Also, the service reports revealed that the situation needed to change.

In this paper, I investigate the idea of multilateralism and multilateral resource integration in the service development context. Second, I focus on obtaining the needs from the stakeholders (i.e. the idea-generation phase of the service development). This paper is my account of the project on the basis of the AR as described by Coghlan and Brannick (2014). The pre-step section deals with the project's context and purpose. This is followed by a short description of the conducted action cycles 1 and 2. I briefly explain the steps, show the outcomes, and then share implications based on the experiences. Thus, this paper tells two stories: the action story, which explains of how things happened, and the research story, which interprets the actions and learning as I examine the experiences through the lens of action research (Coghlan \& Brannick, 2014; McNiff, 2014). 


\section{Framing the action research approach in the service co-creation context}

Research on complex socio-technical systems such as business organisations can be carried out using various traditions, approaches, and perspectives. To clarify this paper's position, I closely examine the action research (AR) orientation, including participatory AR (PAR). Then, I move to the discipline of service marketing and management research (in short, SR), which has been at the frontline of business studies. This discussion continues by providing an understanding of the intertwined nature of these approaches.

Rationale for action research as the research method

AR comprises several streams and perspectives (Coghlan \& Coghlan, 2002; Dick, Stringer, \& Huxham, 2009; Gustavsen, 2008; Reason \& Bradbury, 2008). Coghlan and Brannick (2014) state that the AR approach has both action and research outcomes. Similarly, Reason and Bradbury (2008) emphasised the production of practical knowledge and the practical outcomes from working together with people and 'ideally involving all stakeholders'. The underlying theme in AR is the ability to learn from one another, which suggests that co-created learning is at its core (Glassmann, Bartholomew, \& Hur, 2013; Gustavsen, 2008). The roots of AR emphasise societal changes and local constructivism (Gustavsen, 2008). Since PAR was introduced, its position within the AR field is strengthened and is no longer used only in marginalised communities (Khan \& Chovanec, 2010) .

Kemmis and Taggart (1988) reveal that in PAR both academic researchers and other participants are involved. Applying the PAR methodology means that 1) the investigation of the action is in a specific local context; 2) experimental learning is a result of action reflection cycles; 3) this emergent learning creates a shared conceptual framework among the research participants, who remain partners throughout the project; and 4) the practitioners are engaged in action, becoming coresearchers and co-producers of knowledge, interpretation, and learning (Genat, 2009; Khan \& 
Chovanec, 2010). Moreover, these participants, who are 'authentically involved', collaboratively develop the project to fit their (local) needs, benefit the group, and develop local capabilities. PAR is a valid methodological perspective and fits very well with SR and the stakeholder co-creation approach. For the sake of simplicity, however, I use the term AR throughout the paper.

Popular AR practices are described with cycles of actions. For example, Coughlan and Coghlan (2002) and later Coghlan and Brannick (2014) outlined a comprehensive AR cycle with six separate, overarching-, and systematic action steps, whereas Denscombe’s (2010) cycle, composed of five consecutive phases, is simpler. Both cycle models are similarly logical and partially overlapping content wise, but Coughlan and Brannick’s (2014) model emphasises continuous monitoring during AR. This paper applies this process and the cyclical perspective of AR, which consists of systematic steps or phases of actions, including deliberate inquiry and reflection (Coghlan \& Brannick, 2014; Coghlan \& Coghlan, 2002).

Why service context and co-creation?

The growth of the service sector and the transition to service-based economies has had an impact on all levels of society. The recent change in business thinking from a manufacturing-driven to a service-dominant logic (see Vargo \& Lusch, 2004, 2008) has also changed the way many enterprises view, manage, develop and organise themselves. Understanding this paradigm shift from the production of value for the customer to the co-creation of value with the customer is central. It means that firms (i.e. service providers) can no longer develop services based solely on their own internal processes, knowledge and experiences. Customer insights, needs and experiences are sought, and this can be achieved together through co-creation. I propose that engaging multiple stakeholders in simultaneous joint activities, from various organisations, with different levels of 
hierarchy, and dissimilar professions, may increase needed diversification through the broadness of the information and experiences, and the amount and quality of the development suggestions.

There is abundant literature discussing service approaches (e.g. Carlborg, Kindström, \& Kowalkowski, 2013; Galvagno \& Dalli, 2014) and emphasising the co-creation approach through resource integration (Hatch \& Schultz, 2010; Ind \& Coates, 2013; Lusch, Vargo, \& O’Brien, 2007; Prahalad \& Ramaswamy, 2004a, 2004b, 2004c; Ramaswamy \& Gouillart, 2010). Prahalad and Ramaswamy (Prahalad \& Ramaswamy, 2004b, 2004c) coined the term co-creation and moved away from value co-creation (process) toward co-creation experiences (people) (Leavy, 2013). In an extensive review, Galvano and Dalli (2014) explain that in co-creation, companies and customers are no longer on opposite sides as in the traditional industrial supply and demand model, but create value through interaction. To conclude the co-creation approach deals with the expansion of organisational boundaries to customers and other stakeholders from different organisations and the interactions of co-creators (Roser, Samson, Humphreys, \& Cruz-Valdivieso, 2009) as well as the creation of new value (Roser, DeFillippi, \& Samson, 2013). Rai (2012) describes co-creation as an extension to collaboration. Contrary to collaboration, co-creation involves a shorter and more intensive period of activity. Further, in co-creation, knowledge comes from different disciplines of knowledge while co-creation assumes experience as the primary ability. I agree with the definition of co-creation by Roser et al. (2013, p.4) who state that "co-creation is an interactive, creative and social process between stakeholders that is initiated by the firm” ( i.e. service provider).

Literature is less explicit on how co-creation is achieved. The achievement of co-creation in the ideation phase can be measured by the time taken to develop the new ideas, the number of new ideas, and the originality/ value/ realisability of the ideas (Roser et al., 2009). In this project, cocreation is achieved if the stakeholders actively participate in the service development; and specifically the number of ideas generated and prioritised demonstrates positive co-creation. 
Customer involvement is not necessarily goal driven. Unlike co-creation, it may not produce any further actions or specific outcomes. Co-creation goes beyond customer involvement because of the active, peer-like process of producing new value (Bettencourt et al., 2014).

The developed constructs and concepts of SR discipline have a specific meaning, whereas in other disciplines the terms can be used otherwise. Since the context in this paper is service development, the service perspective is chosen. Service is considered as a joint value creation with varying stakeholding partners such as employees, customers, users, fans, intermediaries, hobbyists, artists, designers, service design professionals, suppliers, authorities, and researchers (Frow \& Payne, 2011; Han, 2010; Payne, Storbacka, \& Frow, 2008; Sanders \& Stappers, 2008; Segelström, 2013; Vargo, 2008). Ramaswamy and Gouillart (2010) emphasised this inclusion of all stakeholders. Thus, there seems to be a wide variety of potential stakeholders, who can bring value to service development. Perhaps the social challenge in contemporary business management is the capabilities for cocreation and orchestration of the co-creative engagement of stakeholders (Leavy, 2013). The premise that multiple stakeholders co-create service (Frow \& Payne, 2011; Payne et al., 2008; Vargo, 2008) indicates that it is meaningful to examine stakeholder interactions, the creation of innovative experience environments, and building the experience platform (Prahalad \& Ramaswamy, 2004b, 2004c). Prahalad and Ramaswamy (2004b, 2004c) suggest the use of basic interaction elements dialogue, access, risk-benefit and transparency (DART) as a model and practical means to facilitate the interactions through rich and two-way dialogue, access to information, acceptance of the risks and benefits, and enabling transparency in all activities. Furthermore, the model entails active interaction, engagement, and inclination to act. As such, it seems a useful model to apply to this research. 
Intertwined nature of selected approaches

Transformation in service thinking fundamentally challenges the habits and rules of management. Likewise, Glassman et al. (2013) state that the starting point of AR is to challenge the habits and rules of the community, and then through collective action, especially a goal-driven activity, to create social change. Similarly to AR, SR encompasses change and learning to understand the needs and demands of the users, consumers, customers, and other stakeholders of the service in order to develop the service that is beneficial for all participants (Prahalad \& Ramaswamy, 2004b, 2004c).

The underlying premises and foundations of AR seem very closely linked to those of SR. Both research traditions draw especially from qualitative research and the case study methodology. Furthermore, both traditions underline the participatory approach, change, learning and the use of ethnographic methods (see Glassmann et al., 2013; Moritz, 2005). Whereas AR does not provide an extensive range of tools to conduct studies, SR stream does, and especially service design methodology (Moritz, 2005; Stickdorn \& Schneider, 2010) entails the participatory approach and provides tools for service development. AR provides the cyclical process, inquiry, and reflection to support service development. These approaches work well together. From the research tradition point of view, this paper has combined AR with the context of service development. Combining them is a unique strength of the present study.

\section{The AR story revealed}

The AR story is about applying co-creation in the service development practices of a large company, and it is based on the experiences from a single case study. Service Innovation through Strategic Stakeholder Integration (SISSI) was an externally funded research project during 2011-2014. The AR approach was determined early in the project. Strictly interpreted, AR is about doing research in and on a person's own organisation. However, Coughlan and Brannick (2014) extend this to those 
who experience. In this project there were four sets of stakeholder groups experiencing an important organisational issue (see Table 1). Hence, this project is also collaborative management research or cooperative inquiry (Coghlan \& Brannick, 2014) in which both co-researchers and managers, and other co-subjects (business practitioners) form a group and engage together both in research and action in a case company.

Table 1. Participants in the study

\begin{tabular}{|c|c|c|}
\hline AR TEAMs & Organisations & Professions/ Roles \\
\hline $\begin{array}{l}\text { 1) The externally composed } \\
\text { customer based stakeholders }\end{array}$ & $\begin{array}{l}\text { Parma Oy, Keslog Oy, Valio Oy, } \\
\text { Puukeskus Oy, Scania Suomi Oy, } \\
\text { Ovenia Oy, Stockmann Oyj, } \\
\text { Caternet Finland Oy, and KONE Hissit Oy }\end{array}$ & $\begin{array}{l}\text { Environmental management, quality control, } \\
\text { logistics, sales, key account management, } \\
\text { development, safety, and sustainability }\end{array}$ \\
\hline $\begin{array}{lll}\text { 2) } & \begin{array}{l}\text { L\&T internal stakeholders } \\
\text { (personnel) }\end{array}\end{array}$ & $\begin{array}{l}\text { L\&T employees (Helsinki, Jyväskylä and } \\
\text { Oulu), Personnel at Elisa Ltd } \\
\text { Waste truck drivers }\end{array}$ & $\begin{array}{l}\text { Environmental specialists, information } \\
\text { technology (IT) development experts, project } \\
\text { managers, and customer service professionals }\end{array}$ \\
\hline $\begin{array}{l}\text { 3) The regulatory body (the national } \\
\text { waste sorting instructions) }\end{array}$ & $\begin{array}{l}\text { The Centre for Economic Development, } \\
\text { Transport and the Environment (ELY) }\end{array}$ & Senior inspector \\
\hline 4) The Laurea researcher team & Laurea University of Applied Sciences & Principal lecturers, lecturer, M.Sc. student \\
\hline
\end{tabular}

Table 1 depicts the participants of this project in more detail. Alongside the internal stakeholders from L\&T, several B2B customer representatives and regulatory authority representatives participated in the project. Researchers came from the Laurea University of Applied Sciences (Laurea). The L\&T project manager was the AR project manager and invited the participants for this study. The author acted as the research project manager.

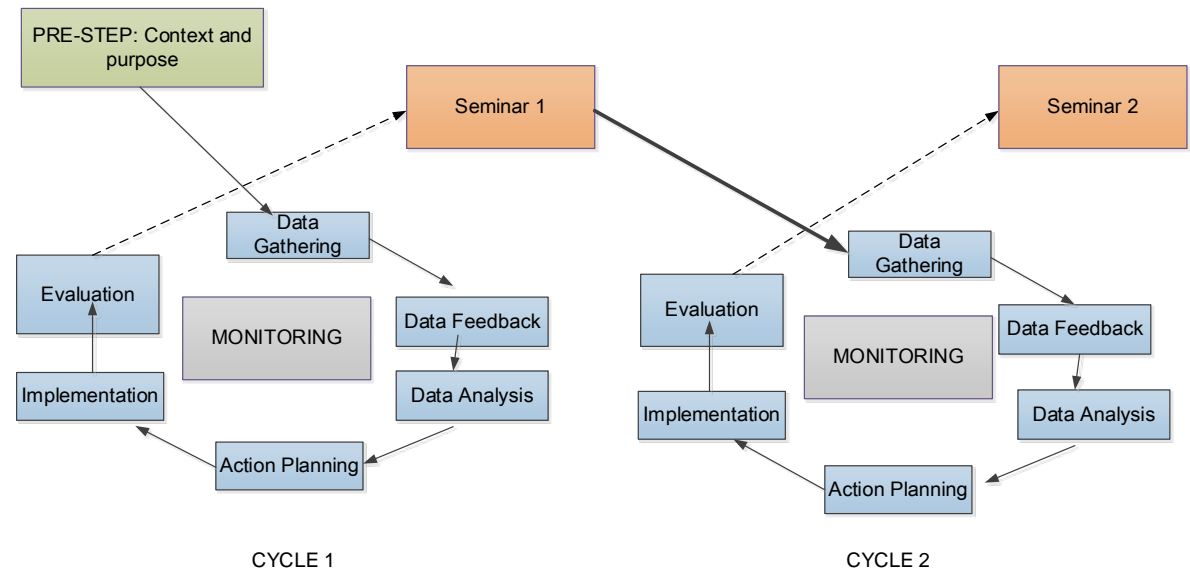

Figure 1. SISSI research design as AR cycle model representation

(Modified from Coghlan and Coghlan, 2002; Coghlan and Brannick, 2014) 
Figure 1 depicts the project design, which included two action cycles. After a full action cycle, the Laurea research team organised an open dissemination seminar for a larger audience to share the results, provide additional knowledge on the topic and discuss how to proceed. Monitoring was performed by the Laurea research team. All data were collected in a research database.

The pre-step phase in the strategic stakeholder integration project

In the pre-step phase the study's context and purpose were defined. Various data collection methods were applied: literature review and secondary data collection for background information, service descriptions and process descriptions. The recycling park was visited to understand the waste management service and to meet with the L\&T representatives for informal discussions. Several L\&T personnel were interviewed by a Laurea student to obtain an extensive in-house perspective. The data were collected qualitatively, analysed and documented by the Laurea research team. A set of criteria for stakeholder selection was designed, and individual stakeholders were briefed about the project, motivated and invited to participate by the L\&T project manager.

The project was executed through a series of face-to-face events, which provided good opportunities to collect data, to investigate activities and to observe the way which stakeholder interaction and service development evolved and unfolded. The Laurea research team and the L\&T team collaborated on analysis of the collected data. Meetings were held as needed to capture and clarify relevant information. Each event was planned beforehand and documented afterwards. The student documented meeting memos, and drafted stakeholder maps and service blueprints. This resulted in a rich amount of plans, timetables, drafts, sketches, memorandums, presentations, and photos of the activities. 
The action cycle 1 - how can we improve waste sorting at the point of origin?

After the pre-step, the project proceeded with the research inquiry. The first cycle began in 2012 with the gathering and analysis of additional data, and examination of the professional practices of the participants. The Laurea research team (lecturers) conducted a series of interviews with the customers following the same interview protocol to understand their points of view. The interviews were organised at the premises of the stakeholders. They were recorded, transcribed and analysed. These thematic interviews provided information for the current state analysis. The interviews revealed that there are issues regarding to the benefits of sorting waste:

“..in sorting waste....locally, what type of waste is feasible to sort and collect...in all locations for example ... it is not worth of sort energy waste in all locations...

Action planning was carried out by the L\&T project manager and the Laurea research team. A halfday service development workshop was planned and scheduled. The materials were prepared and invitations were sent out. In the workshop, the participants were led through a series of structured activities. First, the annual waste management reports were discussed. Second, a key operator of the service, the truck driver, expressed his everyday work life through the storytelling method. Then, an 8x8-method exercise was conducted in two groups. This task required participants to organise issues, ideas, concepts, functions, or matters around the template of an 8x8 canvas on the wall. They first organised their thoughts written on post-it notes and then through collaborative discussion, organised the notes together spatially around themes, in a way that made sense to them. Next, the service was described, investigated and discussed using the CoCo Cosmos tool (Laurea, 2014; Ojasalo \& Keränen, 2011), which is a new board game that helps to describe service in a more concrete manner. The game helps to provide more insight into the practical experiences and to discover improvement opportunities. 
The facilitators (i.e. Laurea research team members) probed the participants throughout the workshop and encouraged them to discuss and share their experiences. Numerous two-directional dialogues were held. One participant questioned the others:

"Have you received any feedback from L\&T that how well you are sorting your waste? I have not got any info on that" Furthermore, the ICT system received attention during the workshop

"We have very much difficulties, me too, if I need to get an overview from the system... what type of waste is originated here and how much. It is very difficult to follow up, because all information needed is not in the system."

Reflection continued in roundtable discussions. The workshop ended with the sharing of experiences from the event and the created, shared understanding. Four service development ideas were selected from the outcomes. The workshop facilitated situational inquiry and reflection; it entailed goal-driven, collaborative actions and focused on practical problems in the participants' specific local context. During the evaluation phase it was found that this study confirmed Khan and Chovanec's (2010) argument that the main distinguishing feature of PAR is that problem identification originates within the community. The project's starting point was the problem suggested by L\&T. However, participating stakeholders changed this problem statement during action cycle 1 . Therefore, the practitioners collaboratively focused the problems to fit their needs and to benefit everyone.

Action cycle 2 - to sort waste better requires holistic understanding of the service

After the seminar, the second cycle was conducted in 2013. A structured service development workshop was planned and scheduled, the materials were prepared and invitations were sent out by the L\&T project manager. The collected and analysed data from action cycle 1 were used again for shared understanding. Different participatory, service design methods were planned and executed in the workshop. The participants familiarised themselves with the waste management truck and its ICT systems with a truck driver's help. The dialogue was lively, and experiences were shared. 
Common problems were identified, and solutions were suggested in a collaborative manner. Then, a brainstorming method was carried out in two separate groups. The participants first considered ideas alone, and then they presented their issues to the group. The facilitators moved the ideas onto a common memory board for grouping, evaluation, and discussion. Then the COCD -box method (Center for Development of Creative Thinking, 1997) was used to collaboratively prioritise the issues raised. The COCD is a 2x2 matrix method, in which the ideas are grouped based on two dimensions: the originality of the idea and the ease (feasibility) of implementation. Next, reflection of the activities took place.

\section{Monitoring step as continuous work phase}

Coughlan and Coughlan (2002) and Coghlan and Brannick (2014) emphasise continuous monitoring throughout the cycle phases. In this project, the monitoring took place in various combinations including the Laurea research team and L\&T representatives. The Laurea research team was mainly responsible for monitoring. The reason for this choice was that the groups were focused on slightly different matters. The L\&T team focused on matters such as ideas, service improvements, implication of the issues raised in events, and their fit with the strategy of the L\&T. The Laurea research team reflected more on the academic issues, methodological choices, method and tool selections, project planning, and documentation of the observations, discussions, meetings, events, and workshops. I found this separation useful, although there were clearly two different goals.

\section{The research story reflections}

As a result of this project, I come to realise that change takes a long time in organisations. As a researcher, I often bring in new ideas, constructs, methods, techniques, and tools with ease and certainty of their success. Thus, it is easy to me forget that not everyone has the same knowledge 
and experience that I have. Yet, this experience has revealed that people are open to new perspectives, tools and techniques, if given enough time. Moreover, they are willing to participate once their point of view is included. In this case, I learned that PAR is valuable to everyone.

The stakeholders' engagement in the co-creation activities in the face-to-face events was positive, productive and successful. However, this required a great deal of planning and scheduling. Through live collaboration, the complex service concepts were not only understood more extensively, but also further developed. This brought joy and motivation to continue. I learned to listen and engage in this project. During the study, I observed strong collaboration among the participants. The multilateral workshop also quickly demonstrated the collective power in identifying challenges. I was surprised at times by how easily everything proceeded. The key to understanding the complexity of resource integration was the realisation that it is not only the participation of the customers that are needed; greater participation on the part of internal experts and extended external stakeholders is equally vital. This was a valuable lesson for the whole research team. During the project, the stakeholders met and worked together for the first time. This was voiced as a positive experience by the participants. Surprisingly, the ICT development manager from L\&T stated in the workshop that

“..this was the first time at L\&T that I met the real customers, had an opportunity to discuss with them, and process ideas together to improve ICT related matters. Now I can present the ideas and requirements based on customer needs to top management..."

He stated that he could now justify development needs to top management based on real customer requirements. The true meaning of this exercise was clearer to everyone: It brought energy and motivation to everyday work.

While the literature describes the AR cycle models in straightforward and systematic steps, I found that the steps were overlapping and iterative in practice. We experienced many changes of plans. I 
found it time consuming to agree on schedules and participatory details. Also, the amount of data collected and generated created an enormous documentation task to meet academic requirements. The business practitioners were happy to proceed with short review of past activities, including photos showing the details and presentation sketches. This implies that from the business practitioners' point of view, the activities can be speeded up. Encounters and sharing of experiences occurred when stakeholders interacted in events. Everyone engaged with active discussion, becoming both co-researchers and co-creators of new knowledge. We learned that despite the firm, hierarchical position or expertise, the challenges and problems were very similar. I found it personally challenging to facilitate and document the project activities with such a vivid discussion. Luckily, I was supported by the whole research team. Personal learning occurred also in the facilitation of events. I was extremely happy to participate with other stakeholders in developing the model for engaging stakeholders.

As the outcomes of this project were reported by the research team in a collaborative manner following SR discipline (Tossavainen, Alakoski, \& Kaartti, 2014), and earlier by me alone (Tossavainen 2013), I found the writing of AR according to the AR traditional method challenging. I have learned from my experience the writing of AR would benefit from collaboration.

\section{Research outcomes}

The outcomes of the project included: 1) a substantial number of ideas for improvements and 2) a thematic analysis of the ideas, prioritisation, and shared understanding and experiences. Table 2 summarises the co-creation achievements of this project and demonstrates the learning achieved. The findings indicate the vulnerability of the service 'value-in-use'. Findings also indicate the cocreation in terms of the number of ideas generated and publications written. The further actions' column details what can be taken away to the next project. 
Table 2. Outcomes of the project.

\begin{tabular}{|c|l|l|l|}
\hline Quantity & Outcomes & Examples & Further actions \\
\hline $145+$ & $\begin{array}{l}\text { Ideas generated to } \\
\text { develop the service }\end{array}$ & See the separate table below & $\begin{array}{l}\text { Project planned for thematic } \\
\text { work to be continued with } \\
\text { stakeholders }\end{array}$ \\
\hline $35+$ & $\begin{array}{l}\text { Professionals involved in } \\
\text { the project }\end{array}$ & $\begin{array}{l}\text { Sales manager, ICT manager, } \\
\text { environmental specialists, logistics } \\
\text { expert, truck drivers, authorities, } \\
\text { researcher-teachers, student }\end{array}$ & $\begin{array}{l}\text { To engage more than one } \\
\text { individual per organisation in } \\
\text { future projects }\end{array}$ \\
\hline $35+$ & $\begin{array}{l}\text { Co-creation events held } \\
\text { to design and develop } \\
\text { the project and service }\end{array}$ & $\begin{array}{l}\text { Meetings, interview sessions, } \\
\text { reflection sessions, workshops, } \\
\text { seminars }\end{array}$ & $\begin{array}{l}\text { To schedule events more } \\
\text { systematically over a shorter } \\
\text { period of time }\end{array}$ \\
\hline 13 & $\begin{array}{l}\text { Organisations } \\
\text { participated }\end{array}$ & $\begin{array}{l}\text { Service provider, B2B customers, } \\
\text { authority, university } \\
\text { (see page 2 for details) }\end{array}$ & $\begin{array}{l}\text { To increase the number of } \\
\text { organizations participating in } \\
\text { the project }\end{array}$ \\
\hline $8+$ & $\begin{array}{l}\text { Publications created } \\
\text { during the project (so } \\
\text { far) }\end{array}$ & $\begin{array}{l}\text { 1 article in Journal of Business } \\
\text { Market Management, reports, several } \\
\text { conference papers (RESER, } \\
\text { NordDesign, NaplesForumOnService, } \\
\text { Cambridge Service Week, AMA } \\
\text { ServSig), 1 Master's thesis }\end{array}$ & $\begin{array}{l}\text { To create publications for } \\
\text { various purposes, such as guide } \\
\text { booklets or cookbooks }\end{array}$ \\
\hline
\end{tabular}

The main purpose of the project was to generate ideas and gather the needs for service improvement. During the project over 145 individual needs and ideas were suggested. The outcomes were discussed, explained, negotiated content wise and prioritised collaboratively based on the needs of the participants. This demonstrates that co-creation took occurred. Table 3 summarises the cocreated ideas into themes and provides a few examples of each theme.

Table 3. Main themes in idea generation summarised

\begin{tabular}{|l|l|l|l|l|}
\hline Theme & $\begin{array}{l}\text { Need/issue, } \\
\text { example 1 }\end{array}$ & $\begin{array}{l}\text { Need/issue, example } \\
\mathbf{2}\end{array}$ & $\begin{array}{l}\text { Need/issue, } \\
\text { example 3 }\end{array}$ & Need/issue, example 4 \\
\hline $\begin{array}{l}\text { Waste sorting } \\
\text { and recycling } \\
\text { vulnerability }\end{array}$ & $\begin{array}{l}\text { Long value chain } \\
\text { with many parties }\end{array}$ & $\begin{array}{l}\text { Source of waste } \\
\text { difficult to determine } \\
\text { once waste picked }\end{array}$ & $\begin{array}{l}\text { Quality through } \\
\text { collaborative } \\
\text { commitment }\end{array}$ & $\begin{array}{l}\text { The sourcing and } \\
\text { purchasing of materials } \\
\text { drives }\end{array}$ \\
\hline $\begin{array}{l}\text { Waste } \\
\text { management }\end{array}$ & $\begin{array}{l}\text { Weighting of waste } \\
\text { and value; waste } \\
\text { bin sizes }\end{array}$ & $\begin{array}{l}\text { Waste collection } \\
\text { schedules, two-way }\end{array}$ & Exceptions & \\
\hline $\begin{array}{l}\text { ICT platform } \\
\text { updates }\end{array}$ & $\begin{array}{l}\text { Real-time chat for } \\
\text { expert advice }\end{array}$ & $\begin{array}{l}\text { Exception } \\
\text { notifications both } \\
\text { ways, feedback }\end{array}$ & $\begin{array}{l}\text { Reports on } \\
\text { customers' needs }\end{array}$ & $\begin{array}{l}\text { Data integration, } \\
\text { compliance, and analysis }\end{array}$ \\
\hline $\begin{array}{l}\text { Finance and } \\
\text { costs }\end{array}$ & $\begin{array}{l}\text { Invoice verification, } \\
\text { billing errors, prices }\end{array}$ & $\begin{array}{l}\text { Recommendations } \\
\text { based on reports }\end{array}$ & $\begin{array}{l}\text { Cost reduction } \\
\text { details }\end{array}$ & Electronic invoicing \\
\hline Training & $\begin{array}{l}\text { Guidance and } \\
\text { instructions, } \\
\text { training programs }\end{array}$ & $\begin{array}{l}\text { Motivation and } \\
\text { commitment towards } \\
\text { recycling } \\
\text { management }\end{array}$ & $\begin{array}{l}\text { Monitoring and follow-up } \\
\text { training }\end{array}$ \\
\hline Reporting & $\begin{array}{l}\text { Progress } \\
\text { monitoring, carbon }\end{array}$ & $\begin{array}{l}\text { Visual and clarity } \\
\text { issues; usability of }\end{array}$ & $\begin{array}{l}\text { Scorecards, } \\
\text { speciality data }\end{array}$ & Bids, offers, FAQs \\
\hline
\end{tabular}




\begin{tabular}{|l|l|l|l|l|}
\hline & $\begin{array}{l}\text { footprint (CO2) } \\
\text { data }\end{array}$ & $\begin{array}{l}\text { the reports in other } \\
\text { systems }\end{array}$ & \\
\hline $\begin{array}{l}\text { Digital tools; } \\
\text { forum and } \\
\text { extranet }\end{array}$ & $\begin{array}{l}\text { Dialogue for bids, } \\
\text { reclamations, } \\
\text { advice }\end{array}$ & $\begin{array}{l}\text { Address-based } \\
\text { history }\end{array}$ & $\begin{array}{l}\text { Contract and } \\
\text { agreement } \\
\text { information }\end{array}$ & $\begin{array}{l}\text { FIXIM -link to } \\
\text { environment system }\end{array}$ \\
\hline Collaboration & $\begin{array}{l}\text { Development } \\
\text { together in future }\end{array}$ & Discussion forum & $\begin{array}{l}\text { Events and } \\
\text { campaigns together }\end{array}$ & Charity work \\
\hline
\end{tabular}

These findings indicate and the experience suggests positive concurrent and direct stakeholder cocreation in service development. And as such, it has a place in the selection of stakeholder integration strategies (Ramaswamy \& Gouillart, 2010). The evidence from this experiment with AR supports the use of direct interaction, participatory methods, canvas tools, and the event method. During the research project, the planning, organisation, and facilitation were provided by the research team. In business organisations, all these tasks can be learned or outsourced. Diverse methods for innovating and developing service require strong facilitation to keep stakeholders involved and active. The inclusion of versatile business professionals in the co-creation events allows for extensive learning opportunities and knowledge transfer. This creates a platform for cocreating new knowledge, learning, and sharing needs.

\section{Conclusion and discussion}

In this paper I have provided insights from an AR study emphasising the importance of multiple stakeholder integration into co-creation activities in a B2B context. The ability to integrate various stakeholder groups such as customers, users, suppliers, subcontractors, state or municipal officials, authorities, other professional groups, and the firm's own employees from various expertise areas into the service development process was confirmed. This is in line with Olsson and Lau (2015) who found that collaboration between different professions may bring new knowledge and perspectives into the design and execution of services. 
These findings validate the DART model suggested by Prahalad and Ramaswamy (2004b). In this study, less attention was given to the dimension of the risk-benefit balance; yet, the preliminary analysis showed that the stakeholders considered the balance throughout the events. Stakeholder cocreation is also about joint problem definition and problem solving (Prahalad \& Ramaswamy, 2004b). The experience in this case confirmed that the starting point given by the service provider changed. The original problem stated by the service provider was less important to the customers and so the focus was redefined by the participants. Thus, this refocus was based on the common perspective co-created by the stakeholders and evaluated by the research team before moving to action cycle 2. Once the stakeholder-relevant problems were solved, the motivation to sort waste was also improved. Only then, would the stakeholders be able to see the results of improved sorting and the value of recycling. This means that the service provider needs to adopt a flexible attitude.

Shared knowledge and experiences provided an in-depth understanding of the service and its practical problems. The stakeholder co-creation that was carried out through two cycles, in which every participant was both a co-researcher and a co-practitioner, provided extensive amounts of meaningful new ideas, novel suggestion, and the motivation to carry on. L\&T received over 145 ideas to develop and improve its service. Furthermore, the stakeholders negotiated about the priority of the ideas moving forward. This was the first time the service provider received a co-created list of ideas to be taken further. As a result of this project, an on-line training module was prototyped and it is currently being tested in pilot cases.

\section{Theoretical and practical implications}

The contribution of this study is evaluated at three comparative strength levels: first, confirming existing knowledge, second, extending new findings to other settings, and third, discovering completely new knowledge. The contribution of this research is three-fold: it contributes to 
contemporary SR, AR and to our understanding of AR in SR context. First, it confirms that AR is a valid research method for examining resource integration. The study contributes the cyclical mode of AR (Coghlan \& Brannick, 2014; Coghlan \& Coghlan, 2002) and confirms that it is pivotal in the investigation of complex socio-technical systems. Second, the PAR methodology (Genat, 2009; Kemmis \& McTaggart, 1988; Khan \& Chovanec, 2010) was supported and found useful. Third, the study extends prior knowledge of AR into the service development context. Despite the popularity of AR, little research has examined stakeholders' integration in a service context. Therefore, this study makes an original contribution by providing a concrete example of the experiences derived from a service project.

For managers and practitioners, the paper shows AR as a vehicle for applying new methods in order to achieve stakeholder engagement, collaboration and co-creation. Encounters with various representatives allow knowledge exchange among experts and stakeholders get to know each another to co-create new knowledge. Starting with small systematic steps will bring value. Stakeholder integration in service development is a strategic issue that can contribute to action planning. Stakeholder engagement improves the service, because it reveals which issues are important to the stakeholders. In turn, this helps the service provider to understand and further develop its service in a co-creative manner toward the desired outcome. Both internal and external experts can be simultaneously engaged in service innovation, but this requires facilitation.

\section{Future research and concluding remarks}

The insights and experiences discussed in this paper offer potential for deeper understanding of multi-stakeholder service development and co-creation that differs from the dyadic one-on-one development model. As there is already some discussion on multi-stakeholder and ecosystem perspectives (Lusch \& Vargo, 2014), I hope the research will become more directed toward this 
multilateral and complex co-creation aspect. Despite the good results achieved during this project, there are several issues to consider. In retrospect, the AR cycles could have been shortened for more efficient progress. Perhaps several but shorter AR cycles would have been more beneficial. The project carried out various methods and tools. It was laborious to execute the planned activities and rigorously document the progress. More research could be directed toward practical application and techniques.

To conclude, this paper promotes the value of multiple stakeholders in developing a service. The action research lens is a valid approach when the co-subjects and stakeholders of the case company are involved in action to deliberately change the way the service currently operates. Co-creation as a form of collaboration brings the stakeholders into the process, and builds commitment to the service. The benefits of co-creation include solving issues, learning from each other, and creating useful knowledge for all parties involved.

\section{References}

Bettencourt, L. A., Lusch, R. F., \& Vargo, S. L. (2014). A service lens on value creation: Marketing's role in achieving strategic advantage. California Management Review, (Fall 2014) 57 (1), 44-66.

Carlborg, P., Kindström, D., \& Kowalkowski, C. (2013). The evolution of service innovation research: A critical review and synthesis. The Service Industries Journal, March, 1-26.

Center for Development of Creative Thinking, C. (1997). Cocd box. Retrieved 5 May, 2015,

Coghlan, D., \& Brannick, T. (2014). Doing action research in your own organization (4th ed.). London, UK.: SAGE.

Coghlan, P., \& Coghlan, D. (2002). Action research for operations management. International Journal of Operations \& Production Management, 22 (2), 220 - 240. doi:

10.1108/01443570210417515 (Permanent URL)

Denscombe, M. (2010). The good research guide for small-scale social research projects (3 ed.): Open University Press.

Dick, B., Stringer, E., \& Huxham, C. (2009). Theory in action research. Action Research Journal, 7 (5), 5-12.

Frow, P., \& Payne, A. (2011). A stakeholder perspective of the value proposition concept. European Journal of Marketing, 45 (1/2), 223-240.

Galvagno, M., \& Dalli, D. (2014). Theory of value co-creation: A systemic literature review. Managing Service Quality, 24 (6), 643-683. 
Genat, B. (2009). Building eemergent situated knowledges in participatory action research. Action research, 7 (1), 101-115.

Glassmann, M., Bartholomew, M., \& Hur, E. H. (2013). The importance of the second loop in educational tecnology: An action science study of introducing blogging in a course curriculum. Action research, 11 (4), 337-353.

Grönroos, C. (2011). A service perspective on business relationships: The value creation, interaction and marketing interface. Industrial Marketing Management (40), 240-247.

Grönroos, C., \& Voima, P. (2013). Critical service logic: Making sense of value creation and cocreation. Journal of the Academy of Marketing Science, 41 (2), 133-150.

Gustavsen, B. (2008). Action research, practical challenges and the formation of theory. Action research, 6 (4), 421-437.

Han, Q. (2010). Practices and principles in service design. Stakeholders, knowledge and community of service. (PhD Doctoral thesis. ), University of Dundee., Dundee, UK.

Hatch, M.-J., \& Schultz, M. (2010). Toward a theory of brand co-creation with implications for brand governance. Journal of Brand Management, 17 (8).

Ind, N., \& Coates, N. (2013). The meanings of co-creation. European Business Review, 25 (1), 8695.

Kemmis, S., \& McTaggart, R. (1988). The action research planner (3rd substantially revised ed.). Victoria, CA: Deakin University Pres.

Khan, C., \& Chovanec, D. M. (2010). Is participatory action research relevant in the canadian workplace? Journal of Contemporary Issues In Education, 5 (1), 34-44.

Laurea, U. o. A. S. (2014). coco tool kit. Retrieved from http://www.laurea.fi/en/cocotoolkit/cocotoolkit/Pages/default.aspx website:

Leavy, B. (2013). Interview with venkat ramaswamy - a ten year perspective on how the value cocreation revolution is transforming competition. Strategy and Leadership, 41 (6), 11-16.

Lusch, R. F., \& Vargo, S. L. (2014). Service-dominant logic. Premises, perspectives, possibilities. : Cambridge Univeristy Press.

Lusch, R. F., Vargo, S. L., \& O’Brien, M. (2007). Competing thrugh service: Insights from service-dominant logic. . Journal of Retailing (83), 5-18.

McNiff, J. (2014). Writing and doing action research (1st ed.). London, UK: SAGE Publications Ltd.

Moritz, S. (2005). Service design. Practical access to evolving field. Retrieved from http://StefanMoritz.com/Book.html website:

Ojasalo, K., \& Keränen, K. (2011). Designing a tool for analysing the current state of a companys co-creation approach. Paper presented at the Cambridge Academic Design Management Conference Cambridge University, UK.

Olsson, E., \& Lau, M. (2015). When one size does not fit all: Using participatory action research to co-create preventive healthcare services. Action Research, 13 (1), 9-29.

Payne, A. F., Storbacka, K., \& Frow, P. (2008). Managing the co-creation of value. Journal of the Academic Marketing Science (36), 83-96.

Prahalad, C. K., \& Ramaswamy, V. (2004a). Co-creating unique value with customers. Strategy and Leadership, 32 (3), 4-9.

Prahalad, C. K., \& Ramaswamy, V. (2004b). Co-creation experiences: The next practice in value creation. Journal of Interactive Marketing, 8 (3), 5-14.

Prahalad, C. K., \& Ramaswamy, V. (2004c). The future of competition. Co-creating unique value with customers. Boston, MA, USA:: Harvard Business School Press.

Rai, S. (2012). Working to understand co-creation. Scenario (4), 35-37.

Ramaswamy, V., \& Gouillart, F. (2010). Building the co-creative enterprise. Harvard Business Review (October), 100-109.

Reason, P., \& Bradbury, H. (2008). The sage handbook of action research (2nd ed.). London, UK: SAGE. 
Roser, T., DeFillippi, R., \& Samson, A. (2013). Managing your co-creative mix:Co-creation ventures in disdinctive contexts. . European Business Review, 25 (1), 20-41.

Roser, T., Samson, A., Humphreys, P., \& Cruz-Valdivieso, E. (2009). Co-creation:New pathways to value. An overview. Promise, 1-21.

Sanders, E. B.-N., \& Stappers, P. J. (2008). Co-creation and teh new landscapes of design. [Preprinto fan article submitted for consideration in CoDesign]. CoDesign.

Segelström, F. (2013). Stakeholder engagement for service design. How service designers identify and communicate insights. . (PhD PhD thesis.), Linköping University., Linköping. Sweden.

Stickdorn, M., \& Schneider, J. (2010). This is service design thinking: Basics, tools, cases. (1 ed.): Wiley.

Tossavainen , P. J. (2013). Beyond sporadic actions: How to approach multi-party stakeholder collaboration in service development. Journal of Business Market Management, 6 (4), 171191.

Tossavainen, P. J., Alakoski, L., \& Kaartti, V. (2014, September 11-13, 2014). Co-designing collaborative idea-generation model with stakeholders. Paper presented at the XXIV International Conference of RESER Services and New Societal Challenges: Innovation for Sustainable Growth and Welfare, Helsinki, Finland.

Vargo, S. L. (2008). Customer integration and value creation : Paradigmatic traps and perspectives. Journal of Service Research, 11 (2), 211-215. doi: 10.1177/1094670508324260

Vargo, S. L., \& Lusch, R. F. (2004). Evolving to a new dominant logic for marketing. Journal of Marketing, 68 (January), 1-17.

Vargo, S. L., \& Lusch, R. F. (2008). Service-dominant logic: Continuing the evolution. Journal of the Academy of Marketing Science, 36 (1), 1-10. 